\title{
Neurological abnormalities in patients treated for hypothyroidism from early life
}

\author{
R. MACFAUL, S. DORNER*, E. M. BRETT, AND D. B. GRANT
}

From The Hospital for Sick Children, Great Ormond Street, London

SUMMARY Neurological and psychological assessment was carried out on 30 patients aged $2 \cdot 7$ to 21 years (mean 9.4) who were being treated for hypothyroidism starting before the age of 2 years. Their IQ scores lay in the normal range (71-122; mean 92.4) but $77 \%$ showed at least one sign of impaired brain function. Clumsiness was found in $33 \%$, behaviour disorders in $23 \%$, speech disorders in $20 \%$, learning disorders in $26 \%$, squint in $53 \%$, nystagmus in $10 \%$, and minor motor disorders in $50 \%$. Many showed several of these features and hypothyroidism in early life appears to lead to widespread impairment of brain function. These neurological findings were equally common in patients in whom treatment started between 4 and 10 weeks of age and patients treated after 10 weeks, suggesting that early detection of hypothyroidism by neonatal screening may be of limited benefit. Children who have been hypothyroid in early infancy require careful assessment to prevent further visual, emotional, scholastic, or vocational difficulties.

The importance of congenital hypothyroidism $(\mathrm{CH})$ as a cause of mental subnormality is well known. Although several studies have shown that the condition is associated with other neurological disorders such as clumsiness and squint, this aspect of congenital hypothyroidism seems to be less widely recognised. The present study was carried out to try to define the incidence and nature of these neurological disorders and to examine their relationship to intellectual development and to earlier symptoms and treatment.

\section{Patients}

Four boys and 27 girls, attending as outpatients at the endocrine department of the hospital for treatment of $\mathrm{CH}$, were studied. Ages ranged from 31 months to 21 years (mean $9.4 \pm 4.2$ years) at the time of investigation. The initial diagnosis of hypothyroidism was made at this hospital in 18 cases and at other hospitals in 13. Details of the early features of the disorder were obtained from hospital records, clinical photographs, and from retrospective histories from the mothers. In all patients, the diagnosis was considered to have been satisfactorily established by

\section{Received 28 December 1977}

*Present address: Wessex Unit for Children and Parents, Milton Ford, Portsmouth, Hants the initial clinical features, low PBI or plasma thyroxine values (available in 26 cases), and the response to thyroid replacement therapy. Only one child was noted to have a palpable thyroid and later studies indicated that her hypothyroidism was owing to a partial defect of iodine-binding by the thyroid. There was a family history of thyroid disease in 7 patients. The mother of one (Case 12) had been hypothyroid since her teens and she had taken thyroxine throughout her pregnancy; antithyroid antibodies were present in the infant's serum at diagnosis. The sister of another patient has a lingual thyroid. In 5 other cases, a grandparent had a thyroid disease of late onset-such as hypothyroidism, thyrotoxicosis, or goitre.

\section{Early symptoms}

In 22 patients (group 1) symptoms such as feeding difficulties, lethargy, or constipation were noted during the first week of life. Symptoms began between ages 4 and 16 weeks in four patients (group 2) and between 4 and 21 months in five (group 3). This division into 3 groups is based on the assumption that some patients in group 1 may have been hypothyroid in utero, while those in groups 1 and 2 were hypothyroid in early infancy, and those in group 3 developed hypothyroidism only in later infancy. 
Details of the incidence of symptoms in group 1 are given in Table 1. There was a wide variation, from 4 to 80 weeks, in the age at which treatment was started in these patients (Table 2). This probably reflects both variability in the severity of symptoms and difficulty experienced in making the diagnosis in infancy.

In 17 patients in group 1 we were able to ascertain the age at which medical attention was sought because of hypothyroid symptoms. In these patients, the average delay before the condition was finally recognised was 8.5 weeks (range 0-32). Details of the onset of symptoms and the start of treatment in patients in groups 2 and 3 are given in Table 2. In each case early replacement therapy, usually with L-thyroxine, was considered adequate and none of the patients was thought to be receiving excessive treatment at the time of the investigation.

Four patients had early illnesses involving the nervous system. One girl (Case 11) had a cardiac arrest during anaesthesia for treatment of a large haemangioma. Hypothyroidism was recognised and treated one week later. Two children had brief febrile convulsions at age 15 months and 26 months. One patient (Case 29) had hypercalcaemia at the time of diagnosis.

A 16-year-old girl who started treatment at 6 weeks has been excluded. She is severely retarded and has a spastic tetraplegia. Apart from the hypothyroidism, there is no indication of the aetiology of her disorder but this differed considerably in degree from that of the other patients and we felt that she should be reported separately.

Because of possible selective social factors leading to the initial referral to the hospital, social classes IV and V were under-represented. There was also a large proportion of girls in this unselected group, even allowing for the usual 2:1 ratio of girls to boys in patients with $\mathrm{CH}$.

\section{Methods}

Family and school observations. Mothers were questioned about clumsiness, behaviour, or speech disorders. Reports (such as the Rutter B2 behavioural

Table 1 Frequency of symptoms in 21 patients symtomatic from first week of life

\begin{tabular}{ll}
\hline Symptoms & $\%$ \\
\hline Feeding difficulty* & 90 \\
Lethargy* & 76 \\
Constipation* & 62 \\
Labour induced for postmaturity & 52 \\
Prolonged neonatal jaundice & 29 \\
\hline
\end{tabular}

*2 of above symptoms $76 \%$; 3 of above symptoms $43 \%$. questionnaire) were completed and inquiries made about co-ordination in 19 of the 25 children attending school. While many children were described as being slightly clumsy, only those in whom this caused moderate difficulties at school or at home were classified by us as clumsy.

Neurological assessment. A full neurological examination was carried out; this included additional tests to detect impaired co-ordination. Interpretation of the findings was largely based on results obtained in normal children by Touwen and Prechtl (1970) and by R. MacFaul (unpublished). (Appendix 1.) These additional tests can be summarised as follows:

Fine movement. Threading 4 beads on to a stick with each hand; building 1 inch bricks; finger nose test with eyes open and closed; pencil grasp; writing and drawing; touching finger tips successively to the tip of thumb; repetitive hand taps.

Gross movement. Balancing and hopping on one leg; walking on a straight line; walking on heels and toes; running, climbing stairs.

The patients were regarded as having a fine or gross movement disorder if three items or more in the respective category were performed at a level more than 2 years behind mental age or if any performance was clearly abnormal.

Alternating movements of the arms. Inability to do this after the mental age of 6 years or a very poor rhythm after the age of 8 years was graded as abnormal.

Involuntary movement. Definite chorea when the fingers and arms were held outstretched for 20 seconds was considered abnormal.

Hyper-reflexia. Brisk tendon reflexes associated with either an increased area from which they could be elicited, clonus on eliciting the ankle jerks or overflow to other muscle groups apart from finger flexion, were scored as abnormal. When the tendon reflexes were abnormal at 3 or more sites hyperreflexia was considered to be present.

Psychometric assessment. Intelligence test scores using the Wechsler intelligence scale for children (WISC), or the Wechsler preschool and primary school intelligence scale, were obtained from the 28 patients aged at least 3 years. Reading ability of children aged at least 7 years was assessed using the Neale analysis and arithmetic skills were judged by the subtests of the WISC. 


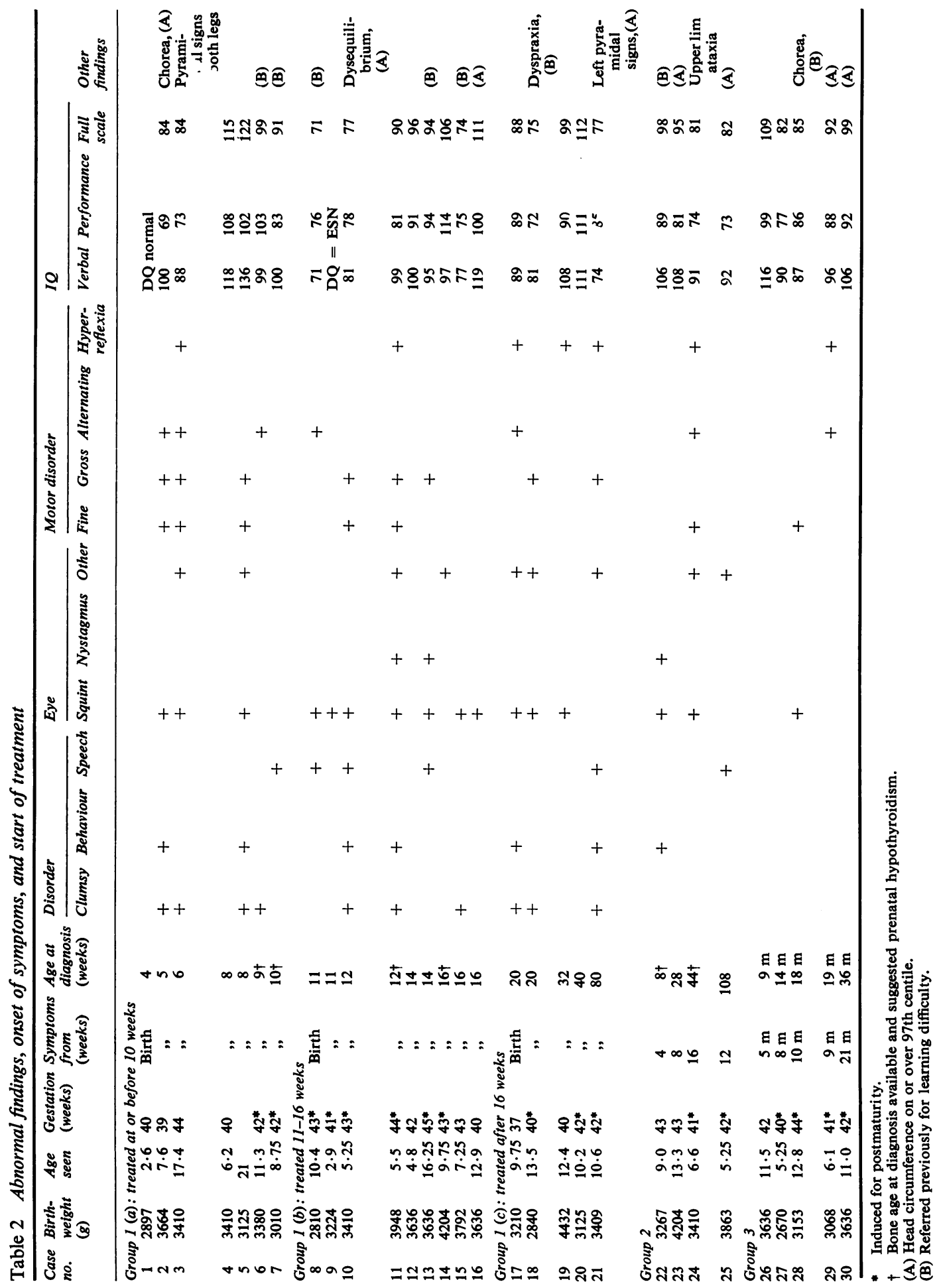




\section{Results}

The abnormal findings, together with the intelligence scores for the patients are given in Table 2 and summarised in Table 3.

Clumsiness. 10 children were graded by us as clumsy from parental description (fine and gross movement in 6 , gross movements in 4). Although the teachers were unaware of our particular interest in co-ordination, clumsiness was reported in 13 of those at school. All those at school and graded as clumsy by us were also reported to be clumsy by the school. The parents of 3 other children described them on direct questioning as being mildly clumsy.

Motor disorders. 15 patients were described as having a minor motor disorder. In these we found poor co-ordination on examination (rather than clumsiness, which we assessed from the history). Details are given in Appendix 2. Our definition of a motor disorder was necessarily arbitrary and we were able to define the disorder more precisely in only 6 patients (Table 2 ). We feel that the movements were abnormal in these cases and we have excluded from the results a few patients who appeared to have only slightly impaired co-ordination. Although the motor disorder in our patients falls within the common definition of cerebral palsy -i.e. a 'disorder of movement and posture due to defect or lesion of the immature brain' (Bax, 1964) - their clinical features were quite unlike those of the classic or mixed forms of cerebral palsy and it would be misleading so to classify them. The disorders in our patients closely resemble those rather unsatisfactorily described as: minimal cerebral palsy, minimal cerebral dysfunction, or the clumsy boy syndrome. We prefer the term 'minor motor disorder' for the difficulties shown in our patients. Only

Table 3 Percentage of children with abnormal findings $(n=30)$

\begin{tabular}{ll}
\hline Disorder & $\begin{array}{l}\text { All patients } \\
\%\end{array}$ \\
\hline None & 23 \\
Clumsiness & 33 \\
Behaviour & 23 \\
Speech & 20 \\
Learning difficulty & 26 \\
Squint & 53 \\
Nystagmus & 10 \\
Minor motor & 50 \\
Full scale IQ & 57 \\
90 or more & 32 \\
76 to 89 & 11 \\
70 to 75 & 42 \\
Verbal/performance discrepancy on IQ of 15 points & \\
or more & \\
\hline
\end{tabular}

2 children showed definite signs of cerebellar disorder. If hyper-reflexia is accepted as a sign of minor pyramidal dysfunction and abnormal alternating movements as a sign of a minor degree of cerebellar dysfunction, there was an equal incidence of pyramidal and cerebellar disorders in our patients.

Speech disorders. Mild speech disorders were present in 6 patients. There were two, aged 5 and 16 years, with stammers, one aged 10 with nasal escape, one aged 8 with mild expressive dysphasia, and two aged 5 and 10, with poor articulation.

\section{Eye abnormalities}

Squint. 16 patients had a squint which was convergent in 13 cases and divergent in 3 cases. In two of these, the movements of one eye were limited. The uncorrected visual acuity in 6 of the patients with squint was normal and in the remainder it was reduced but was not lower than $6 / 18$ in one eye.

Nystagmus. Three children had a high-frequency low-amplitude nystagmus which was phasic on lateral gaze.

Other disorders of eye movements. These were present in 9 patients. In 7, horizontal pursuit of a slowly moving object was jerky despite good attention. In 4 of these there was also difficulty in achieving upward gaze. In 2 difficulty in upward gaze was the only abnormality.

Psychometric results. The mean IQ for all the subjects $(92.4)$ was in the low to normal range and about one standard deviation below the mean score of about 108 found in a random sample of British schoolchildren of similar social class (Rutter et al., 1970b). The mean verbal IQ $(97 \cdot 6)$ exceeded the mean performance IQ by 9.6 points and a discrepancy of 15 points or more was found in 11 children, an incidence three times greater than in the normal population.

Educational attainments were generally consistent with intelligence levels although 9 children had earlier been referred for psychological assessment for learning difficulties.

Behaviour disorders. Teachers' ratings of behavioural disturbance on the Rutter B2 scale were obtained on 19 of the 25 children at school. 5 (26\%) out of the 19 were rated as deviant with a score of 9 points or more. In addition, definite behavioural problems were described in 2 others. The problems described in the teachers' ratings were restlessness, poor attention, etc., or neurotic symptoms-such as 
excessive worrying, fearfulness, or nail-biting. There were no antisocial problems.

Head circumference. Head circumferences tended to be large for height and in only one patient was it below the 10th centile. In 8 patients, the head circumference was on or over the 97th centile and although the height of 3 of these was over the 75th centile, in 5 patients heights ranged from the 50th to the 75th centile. In one patient (Case 10) hydrocephalus was suspected and an air encephalogram was carried out at 4 months with normal results.

Statistical analysis of results. In the 25 patients in groups 1 and 2, there were no significant correlations between neurological scores, full scale IQ results, ages at which treatment was started, and number of symptoms of hypothyroidism during the first week of life including postmaturity or induction after term.
In the whole group of 30 patients, clumsiness was found to be significantly associated with both motor disorders $\left(\chi^{2}=8 \cdot 07, \mathrm{P}=<0.01\right)$, and behaviour disorders $\left(\chi^{2}=8 \cdot 23, P=<0 \cdot 01\right)$. There was also a significant association between motor disorders and behaviour disorders $\left(\chi^{2}=8.4, P=<0.01\right)$ (Fisher's exact test). Clumsiness and eye abnormalities showed no significant association.

A WISC verbal/performance discrepancy of 15 points or more showed no apparent correlation with clumsiness, behaviour or motor disorders, or eye abnormalities.

\section{Discussion}

Our results are in agreement with previous reports of poor co-ordination (Table 4), squints (Kirkland et al., 1972), nystagmus (Schulman and Crawford, 1969), and behaviour disorders (Radwin et al., 1949;

Table 4 Previous neurological studies on treated hypothyroid children

\begin{tabular}{|c|c|c|c|c|c|}
\hline \multirow[t]{2}{*}{ Reference } & \multirow[t]{2}{*}{$n$} & \multicolumn{2}{|l|}{ Motor disorder } & \multirow[t]{2}{*}{ Comment } & \multirow[t]{2}{*}{$I Q$} \\
\hline & & Present & Description & & \\
\hline Lewis et al., 1937 & $\begin{array}{l}89 \\
(34<21 \text { years })\end{array}$ & Most patients & $\begin{array}{l}\text { Slowness of speed in relation } \\
\text { to intelligence }\end{array}$ & & $20 \%$ normal \\
\hline Brown et al., 1939 & 29 & All & $\begin{array}{l}\text { On IQ testing, scores in } \\
\text { performance tasks invariably } \\
\text { slower than other test items }\end{array}$ & & $\begin{array}{l}>1007 \% \\
<8075 \%\end{array}$ \\
\hline Topper, 1951 & 9 & & $\begin{array}{l}\text { EEG study: } 5 \text { had evidence of } \\
\text { 'cerebral dysfunction' }\end{array}$ & & \\
\hline \multirow[t]{3}{*}{ Smith et al., 1957} & 22 & 4 & $\begin{array}{l}\text { Varying degrees of inco- } \\
\text { ordination especially in fine } \\
\text { voluntary movement; coarse } \\
\text { tremor; general spasticity; } \\
\text { shuffling gait; awkwardness, jerky } \\
\text { movements; hyperactive tendon } \\
\text { reflexes }\end{array}$ & $\begin{array}{l}\text { Hypothyroid symptoms } \\
\text { starting before } 6 \\
\text { months. Started therapy } \\
\text { before } 6 \text { months }\end{array}$ & $\begin{array}{l}>9015 \% \\
<5041 \%(n=79)\end{array}$ \\
\hline & 57 & 22 & & $\begin{array}{l}\text { Therapy after } 6 \text { months } \\
\text { or inadequate }\end{array}$ & \\
\hline & & & $\begin{array}{l}\text { Of } 26 \text { with motor disorder } \\
* 10 \text { mild to moderate } \\
\text { incoordination brisk reflexes } \\
* * 16 \text { more severe }\end{array}$ & & \\
\hline Neel et al., 1961 & 54 & 9 & Spastic (6 with squint) & & All 'retarded' \\
\hline Andersen, 1971 & 50 & 25 & $\begin{array}{l}\text { Cerebellar dysfunction (one } \\
\text { spastic). None with gross } \\
\text { neurological disturbance }\end{array}$ & $\begin{array}{l}\text { All treated within } 3 \\
\text { months }\end{array}$ & None given \\
\hline Mãenpää, 1972 & 67 & 22 & $\begin{array}{l}\text { Spasticity, ataxia, or hypotonia } \\
\text { (10 had squint) } \\
\text { None treated within } 2 \text { months had } \\
\text { neurological abnormality }\end{array}$ & & $\begin{array}{l}>8552 \% \\
<7028 \% \\
(n=67)\end{array}$ \\
\hline $\begin{array}{l}\text { Hagberg and Westphal, } \\
1970\end{array}$ & 12 & 6 & Cerebellar ataxia, mild in 4 & & $\begin{array}{l}\text { Ataxic patients } \\
>9015 \% \\
<6050 \%\end{array}$ \\
\hline Wiebel, 1976 & 67 & 28 & $\begin{array}{l}\text { Mild cerebellar ataxia (other } \\
\text { motor abnormalities difficult to } \\
\text { analyse) }\end{array}$ & & $\begin{array}{l}60 \% \text { ataxic } \\
\text { patients retarded }\end{array}$ \\
\hline
\end{tabular}

*Mean IQ 63; ** Mean IQ 37.5 
Money, 1956), in patients treated for hypothyroidism from early life. Similar abnormalities occur in some normal children and could represent the extreme range of normal. However, the high incidence of minor abnormalities and the presence of more definite neurological disorders in some patients suggest that disturbed neurological function due to hypothyroidism in early life was present in many of the patients. While poor nutrition may have contributed to this, the findings in 6 patients with poor weight gain before diagnosis were very similar to those in the patients who had thrived.

The poor co-ordination in our patients was probably owing to a combination of defects, present to a greater or lesser degree in each affected child. We found evidence of impaired function in the visual, pyramidal, extrapyramidal, brain stem, and cerebellar systems in many of our patients. Smith et al. (1957) reported a range of abnormalities similar to those in our patients. Although it might be expected that the cerebellum would be more vulnerable to the effects of hypothyroidism as a result of its rapid growth in early life, we did not find the high incidence of 'pure' cerebellar disorders reported by others (Table 4). Many of their patients were retarded and this implies that they had suffered from more profound effects of hypothyroidism on brain development. This apparent discrepancy may be due to difficulties in describing and interpreting motor disorders in such patients.

Half our patients had squints and many showed nystagmus and jerky eye movements. As the visual acuity was generally normal, these signs probably represent impaired function of the cerebral cortex, brain-stem, or cerebellum.

Further evidence of impaired cerebral function is provided by the reduction in average intelligence and by the behaviour disorders. The incidence of discrepancies between the verbal and performance scores found in many of our patients may reflect perceptual difficulties. However, it should be noted that these discrepancies were not apparently related to other signs of impaired brain function. The explanation for this may lie in a relative elevation of the verbal score owing to social factors, rather than depression of the performance score.

The incidence of behaviour disorders in our patients at school $(26 \%)$ approximates fairly closely to the incidence in epilepsy (26\%) (Rutter et al., 1970a), and handicapping disorders involving the brain $(30 \%)$ and it is higher than the incidence in handicapped children with normal brain function $(10 \%)$ (Seidel et al., 1975), or asthma (10\%) (Graham et al., 1967). This observation, and the close relationship between behaviour disorders, clumsiness, and motor disorders, suggests that there is an organic neurological basis for the behaviour disorders in many children with $\mathrm{CH}$. However, other factors-such as parental anxiety over poor performance or even previous overtreatment-may have contributed to the behaviour problems in some of our patients.

There are few neuropathological studies in patients with early hypothyroidism but air encaphalography performed in 10 patients before treatment showed generalised brain atrophy (Klosovskii, 1963). However, treated $\mathrm{CH}$ is not associated with reduced head size and many patients have head circumferences at the upper limit of normal (Burt and Kulin, 1977). Early publications, reviewed by Smith et al. (1957) and Andersen (1971), described disturbances in the structure of the cerebral cortex and cerebellum with retarded capillary and myelin development. A more recent histological report on a patient by Rosman (1976) described reduced numbers of cortical and cerebellar neurones with reduction in size of basal ganglia, thalamus, cerebral, and brain stem pyramidal tracts.

None of these studies gives information on cellular composition or dendritic connections and for further details we must turn to animal studies. In rats made hypothyroid at birth, histological and biochemical studies have shown changes in both the cerebral cortex and the cerebellum. In both areas, the total cell number remains normal but the cell size is reduced and the architecture distorted by changes in the proportions of different cells (Lewis et al., 1976). The changes in the cerebellum exceeded those in the cerebral cortex. Myelination is delayed but the eventual quantity and composition are normal (Brasel and Boyd, 1975). The most marked effects are on the density of axonal and dendritic connections which may be reduced by up to $70 \%$ (Eayrs, 1966). The behaviour of the rats correlated with these changes (Eayrs, 1971). All these effects were entirely reversed by replacement therapy started within 10 days of birth (Eayrs, 1971; Legrand, 1971). After this, replacement therapy produced only partial response. One action of thyroid hormone may be to regulate the timing and rate of change from one developmental phase of the brain to another and enzymes, for example at the synapses, may be sensitive only for brief critical periods (Hamburgh et al., 1971). In sheep, the only effect of fetal hypothyroidism was impaired cerebellar myelination (Erenberg et al., 1974). However, dendritic arborisation was not specifically studied and hypothyroidism was induced some time after the brain growth spurt had started. It is therefore conceivable that thyroid hormones had already acted by triggering the appropriate developmental phase. Biochemical studies in monkeys made hypothyroid in utero 
merely showed reduced size of cerebral and cerebellar neurones with evidence suggesting reduced electrical function in these neurones and possibly in their dendritic endings (Holt et al., 1973). In terms of brain development, the period from birth to age 25 days in the rat probably corresponds in man to the period from the 18th week of fetal life to age 2-3 years (Dobbing, 1974). If these animal studies can be taken as a guide, it seems likely that axonal and dendritic connections are reduced in number in patients with prenatal or early postnatal hypothyroidism. Many of the findings in the present study could be explained by defective connections leading to widespread impairment of brain function.

In these experimental studies, the exact timing of hypothyroidism was known. While we know that most of our patients developed symptoms of hypothyroidism very soon after birth and many were postmature, suggesting the presence of prenatal hypothyroidism, we are unable to assess the duration and degree of thyroid deficiency before birth. Bone ages at the time of diagnosis were available only in 6 patients (Table 2); absence of the upper tibial epiphysis in these patients implies a period of prenatal hypothyroidism. It is recognised that maternal thyroid hormones do not cross the placenta in sufficient amounts to prevent fetal hypothyroidism (Fisher, 1975). We believe that the variation in timing of onset and severity of postnatal hypothyroidism reflected in groups 1 and 3 almost certainly mirrors similar variation in prenatal hypothyroidism. In so-called 'congenital' hypothyroidism, some patients have an inherited disorder of hormone synthesis (as in Case 16), but most have 'dysgenesis' of the gland in which a small amount of thyroid tissue is present in the thyroglossal tract, the gland is hypoplastic in its usual site, or absent (Carr et al., 1961). Thyroid scans were not carried out on our patients and we have no definite information on this point. The pattern of the disease in infancy, in which hypothyroidism develops some time after birth, could well represent an evolving disorder of the gland though it has been regarded as representing the infant's 'growing out' of the hypoplastic tissue (McGirr and Hutchison, 1955). Retrospective assessment of the severity of hypothyroidism in the neonatal period showed no relationship with either later intelligence or neurological abnormalities. However, comparison of the findings in patients in groups 1 and 3 (Table 2) indicates that vulnerability of the brain to the adverse effects of hypothyroidism becomes less with advancing age.

It is generally accepted that replacement therapy soon after birth will lessen the effects of hypothyroidism on brain development. Whether it can reverse the effects of prenatal hypothyroidism remains to be determined. It is possible that in man, as in the rat, there may be a critical postnatal period during which the effects of earlier hypothyroidism can be reversed. However, our findings of a similar incidence of neurological disorders in patients treated before 10 weeks (Table 2 group 1a) and after 10 weeks (Table 2 group $1 \mathrm{~b}$ ) suggest that any such period must be very short.

Our studies show that despite a level of intelligence within the normal range, children who have been hypothyroid in early life commonly show evidence of widespread minor impairment of brain function (Table 3). Such patients require careful assessment to forestall the development of further difficulties. Behaviour problems should be anticipated and families may require considerable support. Squint should be recognised early to try to prevent amblyopia and loss of binocular vision. Clumsiness requires sympathetic handling especially at school where there may also be learning difficulties. Vocational advice may be needed as some patients may be tempted to earn their living in manual jobs which do

Appendix 1 Standards of normal motor abilities used in this study

\begin{tabular}{|c|c|}
\hline ouwen and Prechtl (1970) & \\
\hline $\begin{array}{l}\text { Hopping on one leg } 4 \text { years } \\
6 \text { years } \\
\text { Toe and heel walking } 7 \text { to } 8 \text { years } \\
\text { Walking along line } \\
\text { Pencil grasp }\end{array}$ & $\begin{array}{l}5 \text { to } 8 \text { times } \\
\text { Average } 13 \text { to } 16 \text { times. } 25 \% \\
\text { more than } 20 \text { times } \\
\text { Majority } 20 \text { or more times } \\
\text { Able to do after } 3 \text { years } \\
3 \text { deviations acceptable up to } \\
7 \text { years } \\
\text { Thumb and index after } 5 \text { years }\end{array}$ \\
\hline
\end{tabular}

R. MacFaul (unpublished) (from a study of 166 children ( 88 boys) in a primary school, described by teachers as normal)

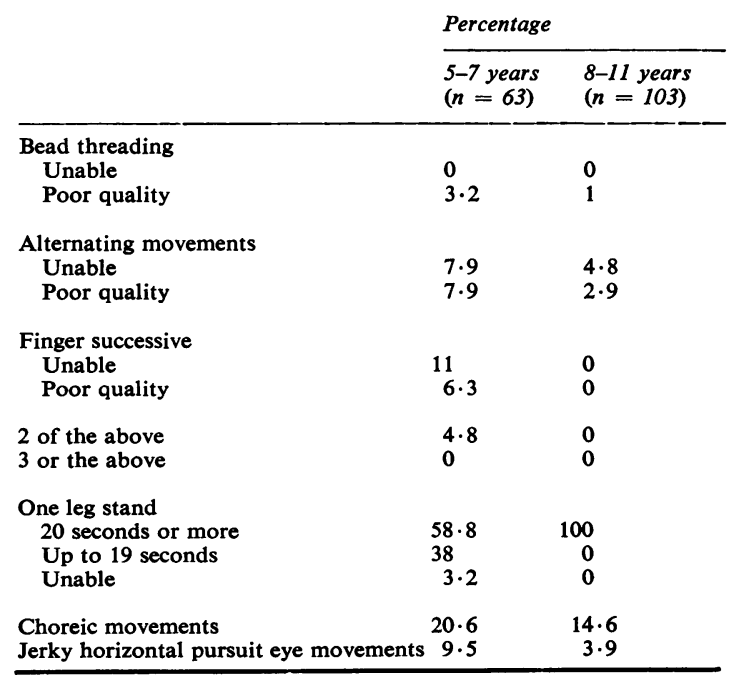


Appendix 2 Abnormalities in children with a motor disorder

\begin{tabular}{|c|c|c|c|c|}
\hline \multirow[t]{2}{*}{ Case } & \multirow{2}{*}{$\begin{array}{l}\text { Age } \\
\text { (years) }\end{array}$} & \multirow{2}{*}{$\begin{array}{l}\text { Full } \\
\text { scale } \\
I Q\end{array}$} & Motor disorder & \multirow[b]{2}{*}{ Description } \\
\hline & & & $\begin{array}{l}\text { Hyper-reflexia, } \\
\text { alternating, gross, fine }\end{array}$ & \\
\hline 2 & $7 \cdot 6$ & 84 & $\begin{array}{l}\text { Fine, gross, } \\
\text { alternating. Chorea }\end{array}$ & $\begin{array}{l}\text { Moderate number of big proximal jerky movements impairing all fine movements. Great } \\
\text { difficulty achieving correct order of finger movements. Unable to stand or hop left leg. } \\
\text { Slapping clumsy running with limited arm movements. Unable to do alternating movements }\end{array}$ \\
\hline 3 & $17 \cdot 4$ & 84 & $\begin{array}{l}\text { Fine, gross, } \\
\text { alternating, hyper- } \\
\text { reflexia. Pyramidal } \\
\text { signs both legs }\end{array}$ & $\begin{array}{l}\text { Poor quality writing. Clumsy threading and building } 1 \text { inch blocks. Tense and excessive } \\
\text { flexion on finger successive movements. Slow on stairs. Unable to stand on either leg more } \\
\text { than } 18 \mathrm{~s} \text {. Odd 'main d'accoucher' posture in arms on hopping, tiptoeing, and heel } \\
\text { walking. Waving on attempt at alternating movements }\end{array}$ \\
\hline 5 & 21 & 122 & Fine and gross & $\begin{array}{l}\text { Poor writing. Block building clumsy, using two hands. Clumsy threading with high } \\
\text { frequency tremor. Finger flexed to palm on finger successive movements. Slow and } \\
\text { deliberate in all tasks. Left foot elevated less than right on heel and toe walking with right } \\
\text { arm adopting fixed flexion posture. Heavy hopping. Awkward alternating movements }\end{array}$ \\
\hline 6 & $11 \cdot 3$ & 99 & Alternating & Waving alternating movements \\
\hline 8 & $10 \cdot 4$ & 71 & Alternating & Unable to do alternating movements \\
\hline 10 & $5 \cdot 25$ & 77 & $\begin{array}{l}\text { Fine and gross mild } \\
\text { dysequilibrium }\end{array}$ & $\begin{array}{l}\text { Clumsy on block building and bead threading. Marked intention tremor of left arm. Slow } \\
\text { repetitive hand taps. Abnormally poor balance. Left foot elevated less than right on heel } \\
\text { and toe walking }\end{array}$ \\
\hline 11 & $5 \cdot 5$ & 90 & $\begin{array}{l}\text { Fine, gross, } \\
\text { hyper-reflexia }\end{array}$ & $\begin{array}{l}\text { Very clumsy on block building and bead threading. Unable to do finger successive } \\
\text { movements. Plans fine movements badly. Unable to hop or balance on one leg or walk on } \\
\text { line. Unable to walk on toes. Stairs one at a time holding on }\end{array}$ \\
\hline 13 & $16 \cdot 25$ & 94 & Gross & $\begin{array}{l}\text { Poor writing, clumsy threading. Poor balance left leg, clumsy slapping running with } \\
\text { reduced arm movements. Unable to walk along line (fell twice) }\end{array}$ \\
\hline 17 & $9 \cdot 75$ & 88 & $\begin{array}{l}\text { Alternating hyper- } \\
\text { reflexia }\end{array}$ & $\begin{array}{l}\text { Poor quality finger successive movements. Poor writing. Slow and careful on stairs. Poor } \\
\text { balance }(9 \mathrm{~s}) \text { right leg. Passive pronation and supination of arm leads to mirror movements } \\
\text { in other arm. Unable to do alternating movements }\end{array}$ \\
\hline 18 & $13 \cdot 5$ & 75 & Gross, dyspraxic & $\begin{array}{l}\text { Poor quality finger successive movements. Poor balance (10 s), } 3 \text { hops right leg. Unable to } \\
\text { walk along line. Slow and holds on going down stairs. Hunched up and awkward on } \\
\text { running. Dyspraxic on dressing and self care }\end{array}$ \\
\hline 19 & $12 \cdot 4$ & 99 & Hyper-reflexia & \\
\hline 21 & $10 \cdot 6$ & 77 & $\begin{array}{l}\text { Gross, hyper-reflexia. } \\
\text { Pyramidal signs left } \\
\text { leg }\end{array}$ & $\begin{array}{l}\text { Poor balance }(5 \mathrm{~s}) \text {, only } 6 \text { hops left leg. Slow and crablike on stairs. Slapping gait, left heel } \\
\text { and toe elevated less than right, tight left heel cord, left plantar upgoing }\end{array}$ \\
\hline 24 & $6 \cdot 6$ & 81 & $\begin{array}{l}\text { Fine, alternating } \\
\text { hyper-reflexia. Upper } \\
\text { limb ataxia }\end{array}$ & $\begin{array}{l}\text { Marked intention tremor in arms. Poor balance }(7 \mathrm{~s}) \text {, only } 3 \text { hops either leg. Unable to do } \\
\text { alternating movements }\end{array}$ \\
\hline 28 & $12 \cdot 8$ & 85 & Fine chorea & Chorea of face and arms impairs all fine movements \\
\hline 29 & $6 \cdot 1$ & 92 & $\begin{array}{l}\text { Alternating hyper- } \\
\text { reflexia }\end{array}$ & Poor balance either leg $(6 \mathrm{~s})$ unable to hop either leg. Unable to do alternating movements \\
\hline
\end{tabular}

not require high intelligence but which call for dexterity. This dilemma is not confined to patients with poor intelligence. For example, one of our patients who is training to be an accountant has great difficulty in tabulating figures and operating a calculator.

\section{References}

Andersen, H. J. (1971). Prenatal damage in hypothyroidism. In Hormones in Development, pp. 559-566. Edited by M. Hamburgh and E. J. W. Barrington. AppletonCentury-Crofts: New York.

Bax, M. C. O. (1964). Terminology and classification of cerebral palsy. Developmental Medicine and Child Neuro$\log y, 6,295-297$.

Brasel, J. A., and Boyd, D. B. (1975). Influence of thyroid hormones on fetal brain growth and development. In Perinatal Thyroid Physiology and Disease, pp. 59-71. Edited by D. A. Fisher and G. N. Burrow. Raven Press: New York.

Brown, A. W., Bronstein, I. P., and Kraines, R. (1939). Hypothyroidism and cretinism in childhood. VI. Influence of thyroid therapy on mental growth. American Journal of Diseases of Children, 57, 517-523.
Burt, L., and Kulin, H. E. (1977). Head circumference in children with short stature secondary to primary hypothyroidism. Pediatrics, 59, 628-630.

Carr, E. A., Jr, Beierwaltes, W. H., Neel J. V., Davidson, R., Lowrey, G. H., Dobson, V. N., and Tanton, J. H. (1961). The various types of thyroid malfunction in cretinism and their relative frequency. Pediatrics, 28, 1-16.

Dobbing, J. (1974). Later development of the brain and its vulnerability. In Scientific Foundations of Paediatrics, pp. 565-577. Edited by J. A. Davis and J. Dobbing. Heinemann Medical: London.

Eayrs, J. T. (1966). Thyroid and central nervous development. Scientific Basis of Medicine Annual Reviews, pp. 317-339.

Eayrs, J. T. (1971). Thyroid and developing brain: anatomical and behavioural effects. In Hormones in Development, pp. 345-355. Edited by M. Hamburgh and E. J. W. Barrington. Appleton-Century-Crofts: New York.

Erenberg A., Omori, K., Menkes, J. H., Oh, W., and Fisher, D. A. (1974). Growth and development of the thyroidectomised ovine fetus. Pediatric Research, 8, 783-789.

Fisher, D. A. (1975). Thyroid function in the fetus. In Perinatal Thyroid Physiology and Disease, pp. 21-32. Edited by D. A. Fisher and G. N. Burrow. Raven Press: New York.

Graham, P., Rutter, M., Yule, W., and Pless, I. B. (1967). Childhood asthma: a psychosomatic disorder? Some epidemiological considerations. British Journal of Preventive and Social Medicine, 21, 78-85. 
Hagberg, B., and Westphal, O. (1970). Ataxic syndrome in congenital hypothyroidism Acta paediatrica Scandinavica, 59, 323-327.

Hamburgh, H., Mendoza L. A., Burkert, J F., and Weil, F. (1971). Thyroid dependent processes in the developing nervous system. In Hormones in Development, pp. 403-415. Edited by M. Hamburgh and E. J. W. Barrington. Appleton-Century-Crofts: New York.

Hanefeld, F., Richer I., Weber, B., and Zabransky. S. (1974). Neurological studies on children with hypothyroidism on long term treatment (abstract). Acta paediatrica Scandinavica, 63,332

Holt, A. B., Cheek, D. B., and Kerr, G. R. (1973). Prenatal hypothyroidism and brain composition in a primate. Nature, 243, 413-415.

Kirkland, R. T. Kirkland, J. L., Roberson, M. C., Librik, L., and Clayton, G. W. (1972). Strabismus and congenital hypothyroidism. Journal of Pediatrics, 80, 648-650.

Klosovskii, B. N., editor (1963). Changes in the nervous system in children with congenital myxoedema. In The Development of the Brain and its Disturbance by Harmful Factors, pp. 152-161. Pergamon: Oxford.

Legrand, J. (1971). Comparative effects of thyroid deficiency and under nutrition on maturation of the nervous system, and particularly on myelination in the young rat. In Hormones in Development, pp. 381-390. Edited by $\mathbf{M}$. Hamburgh and E. J. W. Barrington, Appleton-CenturyCrofts: New York.

Lewis, A., Samuel, N., and Galloway, J. (1937). A study of cretinism in London. Lancet, 1, 1505-1509.

Lewis, P. D., Patel, A. J., Johnston, A. L., and Balazs, R. (1976). Effect of thyroid deficiency on cell acquisition in the postnatal rat brain: a quantitative histological study. Brain Research, 104, 49-62.

McGirr, E. M., and Hutchison, J. H. (1955). Dysgenesis of the thyroid gland as a cause of cretinism and juvenile myxedema. Journal of Clinical Endocrinology and Metabolism, 15, 668-679.

Mäenpää, J. (1972). Congenital hypothyroidism:aetiological and clinical aspects. Archives of Disease in Childhood, 47, 914-923.

Money, J. (1956). Psychologic studies in hypothyroidism. Archives of Neurology and Psychiatry, 76, 296-309.
Neel, J. V., Carr, E. A., Beierwaltes, W. H., and Davidson, R. T. (1961). Genetic studies on the congenitally hypothyroid. Pediatrics, 27, 269-285.

Radwin, L. S., Michelson, J. P., Berman, A. B., and Kramer, B. (1949). End results in treatment of congenital hypothyroidism. American Journal of Diseases of Children, 78, 821-843.

Rosman, N. P. (1976). Neurological and muscular aspects of thyroid dysfunction in childhood. Pediatric Clinics of North America, 23, 575-594.

Rutter, M., Graham, P., and Yule, W. (1970a). A Neuropsychiatric Study in Childhood. Clinics in Developmental Medicine No. 35/36, p. 177. Heinemann Medical: London.

Rutter, M., Tizard, J., and Whitmore, K. (1970b). Education, Health and Behaviour. Longman: London.

Schulman, J. D., and Crawford, J. D. (1969). Congenital nystagmus and hypothyroidism. New England Journal of Medicine, 280, 708-710.

Seidel, U. P., Chadwick, O. F. D., and Rutter, M. (1975). Psychological disorders in crippled children. A comparative study of children with and without brain damage. Developmental Medicine and Child Neurology, 17, 563-573.

Smith, D. W., Blizzard, R. M., and Wilkins, L. (1957). The mental prognosis in hypothyroidism of infancy and childhood. Pediatrics, 19, 1011-1022.

Topper, A. (1951). Mental achievement of congenitally hypothyroid children. American Journal of Diseases of Children, 81, 233-249.

Touwen, B. C. L., and Prechtl, H. F. R. (1970). The Neurological Examination of the Child with Minor Nervous Dysfunction. Clinics in Developmental Medicine No. 38. Heinemann Medical: London.

Wiebel, J. (1976). Cerebellar-ataxic syndrome in children and adolescents with hypothyroidism under treatment. Acta paediatrica Scandinavica, 65, 201-205.

Correspondence to Dr R. MacFaul, Paediatric Department, Cambridge Military Hospital, Aldershot, Hants GU11 2AN. 